\title{
Koperasi dan Gagasan Konstitusi Ekonomi Indonesia Dalam Kerangka Pasal 33 UUD 1945
}

\author{
Oleh \\ Warsono \\ Mahasiswa Program Doktor Ilmu Hukum \\ Fakultas Hukum Universitas 17 Agustus 1945 Semarang \\ Email:
}

\begin{abstract}
Abstrak
Koperasi adalah organisasi ekonomi yang dimiliki dan dioperasikan oleh orang-seorang demi kepentingan bersama. Koperasi melandaskan kegiatan berdasarkan prinsip gerakan ekonomi rakyat yang berdasarkan asas kekeluargaan. Koperasi merupakan potret dari ekonomi konstitusional yang diamanhkan dalam Pasal 33 UUD 1945. Dalam praktik, Koperasi sebagai suatu usaha bersama yang disusun dengan asas kekeluargaan dan bukan usaha swasta yang didorong oleh self-interest. Secara ideal praktik apabila dimaknai secara tegas dan menjadi grand design dari kekuatan ekonomi rakyat memberikan pemahaman bahwa partisipasi dan gotong royong akan mewujudkan sebuah kemandirian bagi bangsa Indonesia. Tulisan ini akan mengkaji bagaimana pemaknaan konsep konstitusi ekonomi Indonesia dalam kerangka Pasal 33 UUD 1945 dan bagaimana eksistensi koperasi dalam konsep konstitusi ekonomi Indonesia dalam kerangka Pasal 33 UUD 1945.
\end{abstract}

Kata Kunci: Koperasi, Konstitusi Ekonomi dalam kerangka Pasal 33 UUD 1945

\section{COOPERATIVES AND IDEAS OF INDONESIAN ECONOMIC CONSTITUTION IN THE FRAMEWORK OF ARTICLE 33 OF THE 1945 CONSTITUTION}

\author{
By \\ Warsono \\ Student of Doctoral Program of Law Science \\ Faculty of Law University of 17 August 1945 Semarang \\ E-mail:
}

Abstract

A cooperative is an economic organization owned and operated by an individual for the common good. The cooperative is based on the principle of the people's economic movement based on the principle of kinship. The cooperative is a portrait of the constitutional economy enshrined in Article 33 of the 1945 Constitution. In practice, the Cooperative as a joint venture is structured with the principle of kinship and not self-promoted private business. Ideally the practice if 
interpreted explicitly and become the grand design of the economic power of the people provides an understanding that participation and mutual cooperation will create an independence for the nation of Indonesia. This paper will examine how the meaning of the concept of Indonesian economic constitution in the framework of Article 33 of the 1945 Constitution and how the existence of cooperatives in the concept of Indonesian economic constitution within the framework of Article 33 of the 1945 Constitution.

Keywords: Cooperatives, Economic Constitution within the framework of Article 33 of the 1945 Constitution

\section{A. PENDAHULUAN}

Undang-undang Dasar 1945 merupakan konstitusi tertulis yang dimiliki Indonesia. Dalam perjalanan sejarah sistem ketatanegaraan bangsa ini, tercatat telah di lakukan pengamandemenan dalam empat tahap, di tahun 1999 sampai dengan tahun 2002. Berangkat dari sebuah tuntutan reformasi, amandemen UUD 1945 diarahkan pada sebuah nuansa demokrasi dan peningkatan kesejahteraan rakyat.

Melalui proses amandemen Undangundang Dasar 1945, konstitusi Republik Indonesia telah mengatur berbagai sendi kehidupan baik politik, keamanan, budaya, hukum dan ekonomi. Namun dalam situasi kekinian gagasan konstitusi ekonomi menjadi sangat baru dan relevan. Logika konstitusional yang dibangun, secara implementatif, ekonomi menjadi basic problem yang dijadikan berbagai kajian dan pokok kebijakan pemerintahan, namun belum memiliki kejelasan pengaturan dalam konstitusi. Perkembangan pemikiran hingga aplikasi dari kebijakan ekonomi dalam konstitusi perlu menjadi fokus dalam pembangunan ekonomi nasional.

Di dalam naskah asli UUD 1945 terdapat materi muatan 71 butir ketentuan dan setelah di amandeman mencakup 199 butir ketentuan. Perubahan tersebut mendasarkan pada ideologi Pancasila sebagai landasan filosofi berbangsa dan bernegara. Pancasila dilihat sebagai cita hukum (rechtsidee) sehingga pada posisi demikian mengharuskan pembentukan hukum positif adalah untuk mencapai ide-ide dalam Pancasila, serta Pancasila dapat digunakan untuk menguji hukum positif.

Dengan ditetapkannya Pancasila sebagai Staatsfundamentalnorm maka pembentukan hukum, penerapan, dan pelaksanaanya tidak dapat dilepaskan dari nilai-nilai Pancasila ${ }^{1}[1]$.

Dalam rumusan UUD 1945 terdapat secara eksplisit ataupun implisit pandanganpandangan dan nilai-nilai fundamental. UUD 1945 disamping sebagai konstitusi politik (political constitution), juga merupakan konstitusi ekonomi (economic constitution), bahkan konstitusi sosial (social constitution). UUD 1945 sebagai sebuah konstitusi negara secara substansi, tidak hanya terkait dengan pengaturan lembaga-lembaga kenegaraan dan struktur pemerintahan semata. Namun Iebih dari itu, konstitusi juga memiliki dimensi pengaturan ekonomi dan kesejahteraan sosial yang tertuang di dalam pasal 33 UUD 1945. $[[1]$

\footnotetext{
1 A. Hamid A. Attamimi, Peranan Keputusan Presiden Republik Indonesia dalam Penyelenggaraan Pemerintahan Negara; Suatu Studi Analisis Mengenai Keputusan Presiden yang Berfungsi Pengaturan dalam Kurun Waktu Pelita I-Pelita IV, Disertasi Ilmu Hukum Fakultas Pascasarjana Universitas Indonesia, Jakarta, 1990, hal., 309

2 Dimensi pengaturan ekonomi dan kesejahteraan sosial yang tertuang di dalam Pasal 33 dan 34 UUD 1945. Pasal ini merupakan konsekuensi dari tujuan dari berdirinya negara Indonesia, hal ini ditunjukkan di dalam Pembukaan UUD 1945 pada alinea ke4, yang rumusannya sebagai berikut: "Kemudian daripada itu untuk membentuk suatu pemerintah
} 
Pasal 33 Undang-Undang Dasar 1945 sebagai landasan bagi sistem ekonomi Indonesia memuat ketentuan sebagai berikut :

1) Perekonomian disusun sebagai usaha bersama berdasar atas azas kekeluargaan.

2) Cabang-cabang produksi yang penting bagi negara dan yang menguasai hajat hidup orang banyak dikuasai oleh negara.

3) Bumi, air dan kekayaan alam yang terkandung didalamnya dikuasai oleh negara dan dipergunakan untuk sebesarbesarnya kemakmuran rakyat.

4) Perekonomian Indonesia diselenggarakan berdasar atas demokrasi ekonomi dengan prinsip kebersamaan, efisiensi, berkeadilan, berkelanjutan, berwawasan lingkungan, kemandirian, serta dengan menjaga keseimbangan kemajuan dan kesatuan ekonomi nasional.

5) Ketentuan lebih lanjut mengenai pelaksanaan pasal ini diatur dalam undang-undang.

Sejarah telah mencatat bahwa UUD 1945 sebelum amandemen meletakkan perekonomian dengan asas kekeluargaan, yang secara tegas menyebut koperasi sebagai salah satu bentuknya. Bung Hatta sebagai founding father atas gagasan koperasi menjelaskan bahwa koperasi salah satu usaha bersama yang sesuai dengan culture di Indonesia

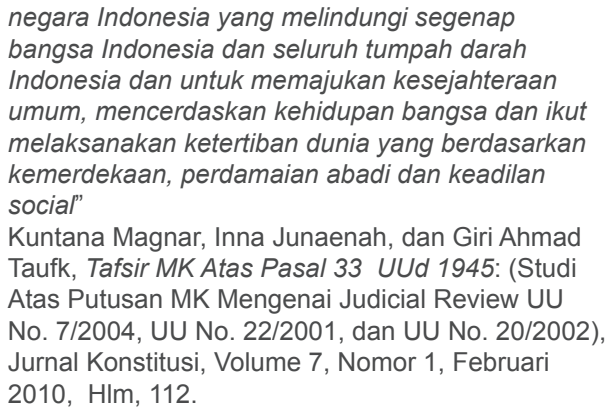

Praktik koperasi merupakan potret dari ekonomi konstitusional yang diamanahkan dalam Pasal 33 UUD 1945. Suatu usaha bersama yang disusun dengan asas kekeluargaan dan bukan usaha swasta yang di dorong oleh self-interest. Secara ideal praktik koperasi apabila dimaknai secara tegas, dan menjadi grand design dari kekuatan ekonomi rakyat akan memberikan pemahaman bahwa partisipasi dan gotong royong akan mewujudkan sebuah kemandirian bagi bangsa Indonesia.

Perekonomian Indonesia yang dirumuskan dalam ayat (1) sampai dengan ayat (5) Pasal 33 UUD 1945 tersebut harus dilihat secara komprehensif dan harus dilihat sebagai permasalahan yang memiliki kompleksitas yang cukup sulit dan mendasar. Bahkan menurut Prof Sri Edi Swasono, dalam kaitannya dengan (Ayat 1), (Ayat 2) dan (Ayat 3) Pasal 33 UUD 1945, maka draft awal Ayat (4) Pasal 33 Amandemen UUD 1945 tahun 2002 merupakan suatu penyelewengan yang akan dapat melumpuhkan disempowering paham "Kebersamaan dan Asas Kekeluargaan", atau minimal mendistrosi Pasal 33 UUD 1945 dengan paham individualisme dan liberalisme ekonomi. ${ }^{3}$

Selebihnya, melalui penerapan dan pengaturan produk hukum yang telah dibuat dan diundangkan, secara sistemik harus dapat tercipta peraturan perundang-undangan sebagai penjabaran roh dan semangat Pasal 33 Undang-Undang Dasar 1945. Adanya beberapa Putusan Mahkamah Konstitusi seperti Putusan Mahkamah Konstitusi Mengenai Judicial Review UndangUndang Nomor 7 Tahun 2004 tentang Pengelolaan Sumber Daya Air, Putusan Mahkamah Konstitusi Mengenai Judicial Review Undang-Undang Nomor 20 Tahun 2002 tentang Ketenagalistrikan, dan Putusan

Sri-Edi Swasono dalam Seminar Implementasi Pasal 33 dan Pasal 34 UUD 1945 Gerakan Jalan Lurus , Jakarta, 6 Agustus 2008 
Mahkamah Konstitusitentang Pembatalan UU NO. 17 Tahun 2012 tentang Perkoperasian, menunjukkan bahwa penerapan pasal 33 UUD 1945 ini dilapangan masih menimbulkan polemik, kontroversi bahkan perlawanan masyarakat.

\section{B. PERMASALAHAN}

1. Bagaimanakah pemaknaan konsep konstitusi ekonomi Indonesia dalam kerangka Pasal 33 UUD 1945 ?

2. Bagaimanakah eksistensi koperasi dalam konsep konstitusi ekononomi Indonesia dalam kerangka Pasal 33 UUD 1945 ?

\section{PEMBahasan}

1. Konstitusi Ekonomi

Konstitusi ekonomi merupakan konsep baru tentang hukum tertinggi di bidang ekonomi. Konstitusi ekonomi (economic constitution) adalah konstitusi kebijakan ekonomi (the constitution of economic policy). Diskursus tentang konstitusi ekonomi relatif masih baru dan cenderung terabaikan oleh para sarjana hukum, para sarjana ekonomi, dan sarjana hukum ekonomi.

Tujuan bernegara adalah menciptakan seluas-luasnya kesejahteraan yang berkeadilan untuk masyarakatnya. Sedangkan tujuan konstitusi ekonomi adalah meningkatkan secara optimal kesejahteraan dan keselamatan ekonomi warga negara, karena penjaminan kesejahteraan dilakukan dengan memastikan hak ekonomi dalam konstitusi. ${ }^{4}[9]$.

Di negara-negara kapitalis-liberal yang menganut dan mendukung sistem dan praktik ekonomi pasar bebas (free market economy), umumnya tidak mencantumkan pengaturan

Jimly Asshiddiqie, dalam makalah Ide Konstitusi

Ekonomi, 2010, hal. 3 tentang sistem dan prinsip-prinsip dasar perekonomian di dalam konstitusinya. Negara-negara kapitalis-liberal meyakini bahwa negara tidak perlu terlalu mengatur dan terlibat dalam kehidupan perekonomian, apalagi jika pengaturan itu dituangkan dalam bentuk hukum setingkat undang-undang dasar atau konstitusi. Itulah sebabnya konstitusi di negara-negara kapitalis liberal tidak disebut sebagai konstitusi ekonomi, tetapi hanya disebut sebagai konstitusi politik, karena cenderung hanya mengatur soal politik.

Pada awalnya, konstitusi yang secara khusus mengatur tentang sistem dan prinsipprinsip dasar perekonomian umumnya hanya ditemui di negara-negara yang mengikuti tradisi sosialisme-komunisme di Eropa Timur yang dipelopori oleh Uni Soviet melalui Konstitusi Tahun 1918. Karena itu, gagasan tentang konstitusi ekonomi pada mulanya hanya berkembang terbatas di lingkungan negara-negara yang menganut aliran sosialisme-komunisme tersebut.

Dalam perkembangannya kemudian, gagasan konstitusionalitasisasi kebijakan ekonomi (konstitusi ekonomi) merambah ke negara-negara Barat setelah negara Irlandia memasukkan prinsip-prinsip dasar perekonomian ke dalam Konstitusi Tahun 1937. Sejak itulah ide konstitusi ekonomi berkembang luas di negara-negara nonsosialisme/non-komunisme. Namun, ini tidak berarti adopsi gagasan konstitusi ekonomi merefleksikan negara-negara tersebut menganut paham sosialisme-komunisme. Gagasan konstitusi ekonomi dewasa ini juga diterima dan dimuat dalam berbagai konstitusi negara-negara yang antikomunis, mulai dari Eropa Barat, Asia, Afrika, hingga Amerika Selatan.

Di samping itu, ide konstitusi ekonomi mudah diterima di negara-negara yang menganut sistem hukum civil law di negaranegara Eropa Kontinental daripada di 
negara-negara yang menganut sistem hukum common law seperti Inggris, Amerika Serikat, Kanada, dan Australia. Tradisi civil law cenderung terbiasa membuat pengaturan yang bersifat tertulis, termasuk di bidang perekonomian. Sebaliknya, tradisi common law cenderung tidak menganggap penting mengatur perekonomian dalam bentuk tertulis. ${ }^{5}$

Dalam konteks persoalan kebijakan ekonomi Indonesia, Undang-Undang Dasar Negara Republik Indonesia Tahun 1945 mengikuti tradisi negara-negara sosialis karena memuat pengaturan tentang sistem dan prinsip-prinsip dasar perekonomian dalam bab tersendiri. Sesudah reformasi konstitusi dari tahun 1999 hingga tahun 2002, Undang-Undang Dasar Negara Republik Indonesia Tahun 1945 juga memuat lebih tegas ketentuan tentang perekonomian dan kesejahteraan sosial seperti dalam tradisi negara-negara sosialis.

Pasal 33 dan Pasal 34 memuat ketentuanketentuan dasar di bidang perekonomian dan kesejahteraan sosial. Bahkan, judul Bab XIV dipertegas menjadi "Perekonomian Nasional dan Kesejahteraan Sosial" dari sebelumnya berjudul "Kesejahteraan Sosial". Isi Pasal 33 dan Pasal 34 telah lebih dilengkapi dan dirinci, sehingga berisi 9 ayat, masing-masing 5 ayat pada Pasal 33 dan 4 ayat pada Pasal 34 . Padahal sebelumnya Pasal 33 hanya terdiri atas 3 ayat, dan Pasal 34 hanya 1 ayat atau pasal tanpa ayat. Ini menunjukkan UndangUndang Dasar Negara Republik Indonesia Tahun 1945 tidak hanya sebagai konstitusi politik, tetapi juga sebagai konstitusi ekonomi.

Di Indonesia hingga saat ini, masih sering muncul perdebatan tentang praktik kebijakan ekonomi nasional terkait dengan soal apakah harus sepenuhnya tunduk pada logika normatif sebagaimana tertuang dalam

5 http://www.jimlyschool.com/read/program/258/ konstitusi-ekonomi
Undang-Undang Dasar Negara Republik Indonesia Tahun 1945 atau berjalan mengikuti saja arus logika pembangunan ekonomi yang berkembang atas dasar pengalaman empirik negara-negara maju dan kaya. Sebagian berpendapat, logika yang pertama berakibat kebijakan ekonomi tidak dapat mengikuti dengan gesit dan luwes perubahan-perubahan dinamis yang terjadi di pasar ekonomi global, nasional, dan lokal yang bergerak cepat setiap waktu. Sebagian lain berpendapat, logika yang kedua berakibat kebijakan ekonomi menjauh dan bahkan melanggar konstitusi dan menjerumuskan perekonomian nasional kedalam dominasi dan hegemoni asing.

Di samping konsep tentang konstitusi ekonomi, sebelumnya juga pernah dikembangkan gagasan tentang Ekonomi Pancasila ${ }^{6}$. Istilah konstitusi ekonomi, ekonomi konstitusi dan ekonomi pancasila, ketiganya memiliki frase sama dengan makna yang berbeda. Konstitusi ekonomi adalah norma dasar yang memuat prinsip dasar ekonomi nasional, sedangkan ekonomi konstitusi yakni perekonomian berdasarkan konstitusi, dan ekonomi pancasila merupakan sebuah falsafah. Ketiganya tidak dapat dipisahkan karena saling terkait dan melengkapi.

Pada amandemen terakhir UUD 1945 ditambahkan penamaan Perekonomian Nasional dalam Bab XIV Pasal 33 dan Pasal 34. Inilah yang menjadi postulat dasar konstitusi ekonomi Indonesia, yang didalamnya terdapat asas dan metode yang dikembangkan untuk menjalankan perekonomian nasional. Asas kekeluargaan tetap menjadi landasan ekonomi, namun penambahan demokrasi ekonomi tidaklah berlaku equal treatment secara mutlak. Disisipkannya kata "efesien berkeadilan" merupakan wujud dari cita-cita demokrasi ekonomi yang berdasarkan keadilan sosial

\footnotetext{
6 Mubiyarto dan Boediono, 1981. Ekonomi
} Pancasila. Yogyakarta: BPFE UGM 
bagi seluruh rakyat Indonesia, dengan memihak pada yang lemah ${ }^{7}[13]$.

Dalam prakteknya implementasi Pasal 33 dan Pasal 34 UUD 1945 sebagai postulat dasar konstitusi ekonomi Indonesia dapat dibangun dan dikembangkan melalui putusan Mahkamah Konstitusi terkait pegujian undang-undang terhadap Undangundang Dasar 1945 (judicial review). Mahkamah Konstitusi sebagai the guardian of constitution, pengawal konstitusi. dibentuk untuk mengawal dan menjaga konstitusi, sehingga setiap perkara yang masuk dengan kategori Pengujian Undang-undang terkait Perekonomian Nasional, dapat diartikan bahwa Undang-undang tersebut tidak sesuai dengan postulat dasar konstitusi ekonomi Indonesia dan merugikan hak konstutusional warga negara.

Dengan demikian prinsip dasar dan dan konsep konstitusi ekonomi nasional Indonesia akan terus terjaga dan berkembang mengingat Putusan Mahkamah Konstitusi bersifat "final dan binding". Pasal 10 ayat (1) huruf a Undang-undang No.4 Tahun 2014 Tentang Mahkamah Konstitusi menyatakan bahwa "Mahkamah Konstitusi berwenang mengadili pada tingkat pertama dan terakhir yang putusannya bersifat final untuk menguji undang-undang terhadap Undangundang Dasar."

Pemaknaan konsep konstitusi ekonomi nasional Indonesia adalah merujuk pada tafsir sebagaimana termuat dalam Putusan Mahkamah Konstitusi terkait pengujian undang-undang terhadap Undang-undang Dasar (judicial review) bidang Perekonomian Nasional.

Hampir di seluruh bidang perekonomian sejak 2003 Mahkamah Konstitusi berdiri, telah lahir putusan yang multidimensional,

Jurnal LPEM Pasal 33 UUD 1945 Harus Dipertahankan, Jangan Dirubah, Boleh Ditambah Ayat, Sri-Edi Swasono, Januari-Maret Vol. No.26 2002 mengenai penguasaan negara, ketidakadilan ekonomi, perusahaan swasta berpraktik, pemodalan asing hingga sumber daya yang menguasai hajat hidup. Diantaranya ada putusan Nomor 36/PUU-X/2012 tentang Pembubaran BP Migas, Nomor 50/PUU-X/2012 tentang Perampasan Tanah, Nomor 27/PUU-IX/2011 tentang Kesejahteraan Pekerja (Outsourching) dan lain sebagainya.

2. Eksistensi Koperasi dalam konsep Konstitusi ekonomi Indonesia

Pasal 33 ayat (1) Undang-Undang Dasar 1945 menyatakan bahwa perekonomian Indonesia disusun sebagai usaha bersama berdasarkan asas kekeluargaan. Penjelasan Pasal 33 antara lain menyatakan bahwa kemakmuran masyarakatlah yang diutamakan bukan kemakmuran orang seorang, dan bangun perusahaan yang sesuai dengan itu ialah koperasi. Penjelasan Pasal 33 UUD 1945 sebelum amandemen, menempatkan koperasi baik dalam kedudukan sebagai sokoguru perekonomian nasional maupun sebagai bagian integral tata perekonomian nasional.

Menurut Kamus Besar Bahasa Indonesia., arti dari sokoguru adalah pilar atau tiang. ${ }^{8}$. Jadi, makna dari istilah koperasi sebagai sokoguru perekonomian dapat diartikan koperasi sebagai pilar atau "penyangga utama" atau "tulang punggung" perekonomian. Dengan demikian koperasi diperankan dan difungsikan sebagai pilar utama dalam sistem perekonomian nasional.

Menurut Muhammad Hatta, koperasi dijadikan sebagai sokoguru perekonomian nasional karena koperasi mendidik sikap, koperasi mempunyai sifat kemasyarakatan, dimana kepentingan masyarakat harus lebih diutamakan daripada kepentingan diri atau golongan sendiri, koperasi digali

8 Kamus Besar Bahasa Indonesia (2000) hal. 768 
dan dikembangkan dari budaya asli bangsa Indonesia, dan koperasi menentang segala paham yang berbau individualisme dan kapitalisme. ${ }^{9}$

Asas kekeluargaan yang menjadi ruh dasar dari ekonomi Indonesia, dalam penjelasan dari naskah asli Undang-undang Dasar 1945 disebutkan secara langsung bahwa koperasilah sebagai wujud dari asas kekeluargaan. Bung Hatta[11] yang menjadi pelaku pertama membangun pondasi ekonomi Indonesia menegaskan bahwa koperasi dengan prinsip kebersamaan dapat menjadi role model dari perekonomian nasional.

Koperasi bukanlah konsep murni pemikiran bangsa Indonesia, koperasi Rochdale sebagai koperasi pertama di dunia tercatat lahir di negara Inggris. Namun demikian di Indonesia koperasi bukanlah hal baru. Kota Purwokerto merupakan kota lahirnya Koperasi pertama di Indonesia tahun 1896 yang diinisiasi oleh R. Aria Wiriatmadja berbentuk Bank Priayi atau simpan pinjam untuk membantu rakyat miskin yang terjerat hutang pada renternir. Sejarah ini menunjukan bahwa bangsa Indonesia telah memiliki modal sosial pendirian koperasi sejak dulu.

Pergulatan Bung Hatta dalam pemikiran ekonomi yang membawa koperasi sampai ke Indonesia bermula saat berkunjung ke negeri Jerman saat sedang melanjutkan studi di negara Belanda. Bung Hatta beranggapan bahwa kedaulatan rakyat ciptaan Indonesia harus berakar dalam pergaulan sehari-hari yang bercorak kolektivisme[15]. Beliau menyatakan bahwa cita-cita perjuangan Indonesia adalah menciptakan terlaksananya dasar-dasar perikemanusiaan dan keadilan sosial. Koperasi adalah bagian integral dari sistem perekonomian nasional tidak menjadi

\footnotetext{
9 Abbas Anwar, Bung Hatta dan Ekonomi Islam,2010,
} Jakarta, PT Kompas Media Nusantara,hlm.193. sub-bagian tersendiri ${ }^{10}$.

Karakteristik Koperasi bukan hanya mencari profit dan membagikan sisa hasil usaha kepada anggota. Hal ini dijabarkan dalam pemikiran atau kerangka dimensi koperasi sebagai mana yang dikemukakan oleh Sri Edi Swasono ${ }^{11}[16]$ yang terdiri dari 4 (empat) fase antara lain :

a. Melihat koperasi sebagai badan usaha ekonomi atau unit produksi yang tunduk pada hukum-hukum ekonomi. Disini kita berbicara masalah profesionalisme, manajemen, kewirakoperasian dan lainlain.

b. Secara makro melihat koperasi sebagai sistem ekonomi nasional, sebagai sistem koperasi, dimana seluruh badan-badan usaha termasuk usaha non koperasi harus tersusun sebagai usaha bersama berdasarkan atas asas kekeluargaan yang berjiwa dan bersemangat koperasi sebagai perwujudan dari demokrasi ekonomi kita.

c. Dimensi gerakan keswadayaan (mandiri) dan kesetiakawanan (solidaritas), yaitu koperasi sebagai movement untuk mewujudkan nilai-nilai demokrasi, terutama demokrasi ekonomi melalui asas dan sendi-sendi dasar koperasi.

d. Dimensi manusia, koperasi dilihat sebagai lembaga pembentukan kepribadian (individualitas), sebagai lembaga guna meningkatkan swadaya dan swakarsa.

Dalam bahasa yang lebih sederhana, keempat hal tersebut jika diperas ide dasar koperasi adalah "kemandirian". "Kemandirian" harus ditempatkan sebagai target utama dalam pembangunan nasional. Target-target konvensional seperti

\footnotetext{
10 http://suroto-ideas.blogspot.com/2012/10/ meluruskan-pemikiran-hatta-tentang.html, diakses 23 Januari 2017

11 http://suroto-ideas.blogspot.com/2011/05/ mewujudkan-koperasi-yang-ideal-menuju. html diakses 23 Januari 2017
} 
pertumbuhan ekonomi, baik nasional, regional maupun sektoral, diberi peran sebagai pendukung terhadap target utama mengurangi "ketergantungan" ekonomi nasional terhadap ekonomi internasional, khususnya kapitalisme global.

Dalam mencapai "kemandirian" itu, suatu sitem ekonomi dan mekanisme ekonomi terkait di dalamnya. Bagi Indonesia sistem dan mekanisme itu disebut "demokrasi ekonomi". Di dalamnya terkandung suatu "moralitas" ekonomi yang berakar pada kedaulatan rakyat, di mana kepentingan masyarakat lebih utama daripada kepentingan orang seorang. Hubungan ekonomi bukan bardasar "asas individualisme" tetapi berdasar atas asas kekeluargaan. Masalah ekonomi bukan hanya persoalan persaingan dan bersaing, tetapi juga kerjasama dan bekerjasama. ${ }^{12}$

Secara logika pasar yang dikembangkan oleh koperasi adalah pasar yang adil (fair market), yang berbeda dengan gagasan kapitalisme yang menghendaki pasar bebas (free market). Walaupun sama-sama menggunakan instrument perusahaan, koperasi sungguh berbeda dalam substansinya, kalau kapitalisme menyandarkan laba yang sebesar-besarnya (profit oriented), maka koperasi dilandaskan pada konsep nilai manfaat (benefit oriented).

Dalam sejarah perkembangan koperasi di Indonesia, praktek implementasi perkoperasian baik melalui pengaturan kebijakan dan regulasi peraturan perundangundangan. sering kali melupakan spirit utama "kemandirian" yang menjadi roh koperasi. Sebagai contoh, prinsip Koperasi adalah dibangun dari semangat orang bukan modal namun kebijakan Pemerintah pada zaman orde baru membentuk Koperasi Unit Desa (KUD) secara top-down sehingga menyebabkan koperasi tidak berkembang.

12 Sri edi swasono, Ekspose Ekonomika: Mewaspadai Globalisme dan Pasar Bebas, Yogyakarta : Pusat Studi ekonomi Pancasila, 2003, hal vii
Oleh karena koperasi adalah wujud dari ekonomi kerakyatan yang berorientasi pada kemandirian ekonomi yang berlandasan asas kekeluargaan, oleh karenanya banyak pemikiran keliru yang mendukung koperasi melalui pemberian 'ikan' bukan 'kail', sehingga persepsi ini sebagai salah satu sesat pikir ekonomi kita yang kemudian menjadikan koperasi kita tidak berkembang dengan baik dan terkurung dalam sistem yang sempit yang dipandang dalam dimensi mikro-organisasi atau bisnis semata-mata.

Palaksanaan asas demokrasi ekonomi di Indonesia mewajibkan Pemerintah memberikan porsi yang sama tidak hanya ekonomi swasta dan pemerintah yang berjalan namun juga ekonomi (milik) rakyat yang memiliki kedaulatan. Sehingga dibutuhkan good will, keberpihakan dan politik hukum untuk menjadikan koperasi berjalan dengan baik. Koperasi masih mewarnai di Indonesia, namun hanya beberapa saja yang menjalankan prinsipprinsip dan jati diri koperasi secara benar, hal inilah yang harus menjadi kontrol agar tidak ada pelaku sandiwara ekonomi berkedok koperasi. Fungsi fasilitator dan regulator dari negara diperlukan dengan membuat produk hukum yang sesuai dengan tujuan kesejahteraan sosial. [17].

Dengan demikian mendasarkan pada Penjelasan Pasal 33 ayat (1) Undangundang Dasar 1945, hingga saat ini koperasi merupakan salah satu role model dari ekonomi kerakyatan dengan asas kekeluargaan. Pemerintah berada dalam garis terdepan untuk mendesign the rule of law, sebagai dasar pelaksanaan berkoperasi secara demokratis, pemerintahpun akan berperan dalam stabilisasi persaingan usaha antara perusahaan swasta, perusahaan negeri dan koperasi . Dengan kata lain pemerintah bertindak sebagai regulator dan fasilitator dalam menguatkan perekonomian yang sesuai dengan amanah konstitusi, dengan berorientasi pada kemandirian ekonomi. 
Pada akhirnya pekerjaan utama yang harus dilakukan adalah menjadikan koperasi bukan hanya sebagai prasyarat formal amanah konstitusi, namun memahami cara berkoperasi dalam bingkai kemandirian (ekonomi) masyarakat.

3. Koperasi pasca Putusan Nomor $28 /$ PUU-XI/2013

Gabungan Koperasi Pegawai Republik Indonesia Propinsi Jawa Timur, Pusat Koperasi Unit Desa Jawa Timur, Pusat Koperasi Wanita Jawa Timur, Pusat Koperasi Annisa Jawa Timur, Pusat Koperasi BUEKA Assakinah Jawa Timur, GabunganKoperasi susu , Agung haryono, dan Mulyono . mengajukan permohonankepada MK untuk menguji. Pasal 1 angka 1, Pasal 50 ayat (1), Pasal 55 ayat (1), Pasal 56 ayat (1), Pasal 66, Pasal 67, Pasal 68, Pasal 69, Pasal 70, Pasal 71, Pasal 72, Pasal 73, Pasal74, Pasal 75, Pasal 76, Pasal 77, Pasal 80, Pasal 82, dan Pasal 83, Undang-undang No. 17 tahun 2012 tentang Perkoperasian.

Sejumlah pasal tersebut mengatur norma badan hukum koperasi, modal penyertaan dari luar anggota, kewenangan pengawas dan dewan koperasi dalam undang-undang tersebut telah mencabut dari sebagian kedaulatan rakyat, demokrasi ekonomi, serta asas kekeluargaan dan kebersamaan yang dijamin oleh Konstitusi. Maka dari itu mereka mengajukan uji materiil terhadap pasal-pasal yang terkadung dalam undang-undang Perkoperasia tersebut.

Dalam hal pengujian undang-undang yang menjadi kewenangan Mahkamah Konstitusi adalah menguji secara konstitusionalitas suatu undang-undang dan menguji sejauh mana undang-undang yang bersangkutan sesuai atau bertentangan denganUUD 1945. Manakala Mahkamah Konstitusi memandang suatu undang-undang bertentangan dengan UUUD 1945 maka undang-undang tersebut tidak mempunyai kekuatan hukum mengikat.

Dalam Pertimbangan Putusannya atas pengajuan judicial review Undang-undang No. 17 tahun 2012 tentang Perkoperasian tersebut,
Ketua Majelis hakim Mahkamah Konstitusi menilai Pasal 1 angka 1 Undang-undang Koperasi yang menyebut koperasi hanya berorientasi pada makna koperasi sebagai entitas yang bernilai materialitas dan bukan pada penempatan serta keterlibatan manusia (orang-orang) dalam proses terbentuk dan keberlangsungan hidup koperasi. Hal ini menempatkan manusia menjadi objek badan usaha dan bukan subjek dari koperasi berdasarkan tafsir historis, Pendirian koperasi oleh orang perseorangan sebagaimana definisi koperasi dalam Undang-undang Perkoperasian tidak disinggung sama sekali oleh para ahli maupun ICA atau ILO. ICA dan ILO justrusangat jelas menandaskan bahwa Koperasi adalah perkumpulan orangorang.

Dengan demikian salah besar bila definisi koperasi dititikberatkan pada pendirian koperasi yang dilakukan oleh orang perseorangan. Penggunaan frasa "didirikan oleh orang perseorangan" pada batasan pengertian koperasi dalam Pasal 1 angka 1 Undang-undang Perkoperasian yang menjadikan koperasi mirip dengan ketentuan pendirian commanditaire vennootschap $(\mathrm{CV})$.

Sebagaimana terdapat dalam Pasal 19 KUHD (Kitab Undang-undang Hukum Dagang) yang menyatakan, "Perseroan yang terbentuk dengan cara meminjamkan uang atau disebut juga perseroan komanditer, didirikan antara seseorang atau antara beberapa orang perseroan yang bertanggung jawab secara tanggung- renteng untuk keseluruhannya, dan satu orang atau lebih sebagai pemberi pinjaman uang".

Bahkan Perseroan Terbatas (PT) saja sebagai sebuah badan hukum yang jelasjelas berorientasi mencari keuntungan, tidak didefinisikan sebagai badan hukum yang didirikan oleh orang perseorangan. Definisi PT dalam Pasal 1 Undang-undang Nomor 40 Tahun 2007 tentang Perseroan Terbatas menyebutkan, "Perseroan Terbatas, 
yang selanjutnya disebut perseroan, adalah badan hukum yang merupakan persekutuan modal,didirikan berdasarkan perjanjian, melakukan kegiatan usaha dengan modal dasar yang seluruhnya terbagi dalam saham dan memenuhi persyaratan yang ditetapkan dalam undang-undang ini serta peraturan pelaksanaannya". Definisi koperasi dalam undang-undang Perkoperasian menunjukkan political will dari pembentuk undangundang yang menyamakan koperasi dengan perusahaan (PT,CV,UD,Firma, dan Perusahaan Perorangan). Koperasi bukanlah PT yang diberi nama Koperasi. Pemilik PT adalah para pemegang saham dan pelanggan PT adalah para konsumen yang membeli barang dan jasa dariPT itu. Sedangkan pemilik Koperasi adalah juga pelanggannya sendiri. Jika PT berusaha mencari laba yang dipungut dari para pelanggannya, maka Koperasi tidak mencari laba. sebab, tidak masuk akal memungut laba pada diri sendiri, karena pelanggan adalah sekaligus pemilik yang sama.

Penjelasan Pasal 33 UUD 1945 menyatakan bahwa dalam Pasal 33 UUD 1945 tercantum dasar demokrasi ekonomi, produksi dikerjakan oleh semua, untuk semua di bawah pimpinan atau pemilikan anggotaanggota masyarakat. Kemakmuran masyarakatlah yang diutamakan, bukan kemakmuran orang seorang. Sebab itu perekonomian disusun sebagai usaha bersama berdasar atas asas kekeluargaan. Bangun perusahaan yang sesuai dengan itu ialah koperasi

Selanjutnya, Mahkamah Konstitusi dalam putusannya yang tertuang dalam Putusan Nomor 28 /PUU-XI/2013 memberikan pertimbangan-pertimbangan yang pada sebagian pokoknya sebagai berikut:

Menimbang berdasarkan seluruh pertimbangan hukum Hakim yang di dasar dengan pengujian yang telah dilakukan terhadap UU No 17 Tahun 2012 Tentang Perkoperasian terutama pasal- pasal yang dimohonkan untuk di uji yaitu ketentuan filosofis pasal 1 angka 1 , pasal 37 ayat 1 huruf $f$, pasal 50 ayat 1 huruf a, pasal 50 ayat 2 huruf a dan e, pasal 55 ayat 1 , pasal 56 ayat 1 , pasal 57 ayat 2 , BAB VII yang terdiri atas pasal 66, pasal 67, pasal 68, pasal 60, pasal 70, pasal 71, pasal 72, pasal 73 , pasal 74, pasal 75, pasal 76, pasal 77, serta pasal 80, pasal 82, pasal 83, pasal 84 Undang-Undang Nomor 17 Tahun 2012 tentang Perkoperasian. (Lembaran Negara Republik Indonesia Tahun 2012 Nomor 212, Tambahan Lembaran Negara Republik Indonesia Nomor 5356)

Menimbang berdasarkan seluruh pertimbangan diatas, oleh karena pengertian koperasi sebagaimana diatur dalam UU $17 / 2012$, filosofinya ternyata tidak sesuai dengan hakikat susunan perekonomian sebagai usaha bersama dan berdasarkan asas kekeluargaan yang termuat dalam Pasal 33 ayat 1 UUD 1945 sebagaimana dipertimbangkan diatas. Demikian pula pengertian tersebut telah ternyata dielaborasi dalam pasal-pasal lain didalam UU 17/2012, sehingga disuatu sisi mereduksi atau bahkan menegasikan hak dan kewajiban anggota dengan menjadikan kewenangan pengawas terlalu luas, skema permodalan yang mengutamakan modal materiil dan financial yang mengesampingkan modal sosial yang justru menjadi ciri fundamental koperasi sebagai suatu entitas khas pelaku ekonomi berdasarkan UUD 1945. Pada sisi lain koperasi menjadi sama dan tidak berbeda dengan Perseroan Terbatas, sehingga hal demikian telah menghilangkan koperasi kehilangan ruh konstitusionalnya sebagai entitas pelaku ekonomi khas bagi bangsa yang berfilosofi gotong-royong.

Dengan demikian, menurut Mahkamah, meskipun Permohonan para Pemohon hanya mengenai pasal tertentu, namun oleh karena pasal tersebut mengandung materi muatan 
norma substansial yang menjadi jantung UU 17/2012, sehingga jikapun hanya pasal-pasal tersebut yang dinyatakan bertentangan dengan UUD 1945 dan tidak mempunyai kekuatan hukum mengikat maka akan menjadikan pasal-pasal yang lain dalam UU 17/2012 tidak dapat berfungsi lagi. Oleh karena itu permohonan para Pemohon harus dinyatakan beralasan menurut hukum untuk seluruh materi muatan UU 17/2012.

Menimbang, berdasarkan seluruh pertimbangan tersebut di atas dan untuk menghindari kevakuman hukum di bidang koperasi yang dapat menimbulkan ketidakpastian dan ketidakadilan maka untuk sementara waktu, sebelum terbentuknya Undang-Undang Perkoperasian sebagai pengganti Undang-Undang a quo maka demi kepastian hukum yang adil Undang-Undang Nomor 25 Tahun 1992 tentang Perkoperasian (Lembaran Negara Republik Indonesia Tahun 1992 Nomor 116, Tambahan Lembaran Negara Republik Indonesia Nomor 3502) berlaku untuk sementara waktu.

Akibat hukum yang ditimbul dari satu putusan hakim jika menyangkut pengujian terhadap undang-undang atas UndangUndang Dasar (judicial review) diatur dalam Pasal 58 Undang-Undang Mahkamah Konstitusi yang menyatakan: :"Undangundang yang diuji oleh Mahkamah Konstitusi tetap berlaku, sebelum ada putusan yang menyatakan bahwa undang-undang tersebut bertentangan dengan Undang-Undang Dasar Negara Republik Indonesia Tahun 1945."

Dengan demikian dari putusan Mahkamah Konstitusi Nomor 28 /PUU$\mathrm{XI} / 2013$ dapat disimpulkan bahwa UU Nomor 17 Tahun 2012 dinyatakan batal dan tidak berlaku lagi. Sehingga jelas bahwa status hukum perkoperasian Indonesia yang diatur dalam UU Nomor 17 Tahun 2012 Tentang Perkoperasian sudah tidak mempunyai kekuatan hukum mengikat karena dalam dalam Amar Putusannya
Mahkamah Konstitusi menyatakan UndangUndang tersebut bertentangan dengan UUD 1945. Selanjutnya untuk mengisi kevakuman hukum yang dapat menimbulkan ketidakpastian dan ketidakadilan ketentuan hukum yang mengatur tentang Perkoperasian Indonesia dikembalikan untuk sementara waktu ke Undang-Undang yang lama yaitu Undang-Undang Nomor 25 Tahun 1992.

Beberapa kalangan menilai Putusan Mahkamah Konstitusi Nomor 28 /PUUXI/2013 ini bersifat Ultra Petita (memutuskan melebihi apa yang diminta oleh pemohon) karena membatalkan keseluruhan isi UU Nomor 17 Tahun 2012 sementara yang dimintakan untuk diuji hanya beberapa Pasal.

Atas anggapan tersebut Mahkamah Konstitusi berpendapat :

1. Pasal Undang-undang yang diminta diuji adalah merupakan "jantungnya" undang-undang sehingga seluruh pasal tidak bisa dilaksanakan;

2. Praktek ultra petita lazim dilakuklan di Mahkamah Konstitusi seluruh dunia;

3. Dalam perkembangan Yurisprudensi pengadilan perdata, Ultra Petita diijinkan;

4. Terkait pengujian undang-undang yang menyangkut kepentingan umum akibat hukumnya yang bersifat erga omnes berbeda dengan hukum perdata ( privat)

5. Kebutuhan kemasyarakatan dalam hal menuntut Ultra Petita tidak berlaku mutlak

6. Jika kepentingan umum menghendaki hakim tidak boleh terpaku pada permohonan ( petitum )

7. Permohonan keadilan (ex aquo et bono) dianggap secara hukum diajukan pula dan mengabulkan hal yang tidak diminta.

Problematika yuridis lain menyangkut pengaturan Koperasi selanjutnya adalah 
terkait dengan kapasitas kewenangan sebagai negative legislator.

Istilah Positive Legislator dan Negative Legislator dalam hukum positif di Indonesia memang tidak diatur secara eksplisit dalam perundang-undangan. Akan tetapi secara implisit dan kontekstual kita mengenal ,bahkan mempraktikkan kedua istilah hukum yang memiliki pengertian saling berlawanan tersebut. Istilah Positive Legislator dipahami sebagai wilayah kerja para legislator (pemegang kekuasaan legislatif), bukan wilayah kerja lembaga peradilan (yudikatif), dimana lembaga legislatif ini memiliki kewenangan untuk membentuk sebuah norma. Sebaliknya, Negative Legislator merupakan wewenang legislasi yang bersifat negatif/pasif, yakni hanya untuk menghapus/ membatalkan suatu norma atau menyatakan suatu norma hukum tidak mengikat. Wewenang inilah yang berada dibawah lembaga yudikatif terutama berkaitan dengan pengujian sebuah norma.Hal inilah yang ditegaskan oleh Hans Kelsen ${ }^{13}$

Gagasan itulah yang kemudian meletakkan keniscayaan akan adanya kekuasaan khusus untuk mengontrol hasil legislasi yang dikeluarkan lembaga legislatif. Kemudian, gagasan ini dibaca oleh Bojan Bugaric sebagai upaya Hans Kelsen untuk memunculkan legislatif positif (positive legislator) yang diperankan oleh parlemen, sedangkan model legislatif negatif (negative legislator) diperankan oleh Mahkamah Konstitusi ${ }^{14}$

Di Indonesia sendiri berdasarkan norma-norma yang diatur di dalam konstitusi yaitu UUD NRI 1945 kewenangan negative legislator dimiliki oleh 2 (dua) lembaga kekuasaan kehakiman yaitu MK dan MA. Untuk MK negativelegislator digunakan untuk

13 Saldi Isra, 2010, Negative Legislator, http:// www.saldiisra.web.id/index.php/21-makalah/ makalah1/302-negative-legislator.html

14

ibid membatalkan UU yang bertentangan dengan UUD 1945, sementara untuk MA negative legislator digunakan untuk membatalkan peraturan perundang-undangan di bawah UU yang bertetangan dengan UU. Untuk positive legislator, kewenangannya dimiliki oleh 2 (dua) lembaga negara yaitu: DPR dan Presiden sebagaimana yang diatur di dalam Pasal 5 ayat (1) dan Pasal 20 UUD NRI 1945. Dalam melakukan "Constitutional Review" UU terhadap UUD maka MK Konstitusi hanya mempunyai Hak untuk menyatakan batal atau tidak sah UU tersebut.

Dalam kaitan ini, maka dalam melaksanakan kewenangannya, terutama dalam melakukan pengujian atau judicial review undang-undang terhadap UUD, MK hanya boleh menafsirkan isi UUD sesuai dengan original intent yang dibuat melalui perdebatan oleh lembaga yang berwenang menetapkannya. MK hanya boleh menyatakan sebuah undang-undang bertentangan atau tidak dengan UUD dan tidak boleh memasuki ranah legislatif (ikut mengatur) dengan cara apa pun. Pada umumnya pembatasan tugas yang demikian dikaitkan dengan pengertian bahwa DPR dan pemerintah adalah positive legislator (pembuat norma) sedangkan MK adalah negative legislator (penghapus atau pembatal norma. ${ }^{15}$

Dengan demikian Putusan Mahkamah Konstitusi yang putusan Mahkamah Konstitusi Nomor 28 /PUU-XI/2013 yang menyatakan UU Nomor 17 Tahun 2012 dan tidak berlaku lagi serta untuk mengisi kevakuman hukum pengaturan koperasi dikembalikan untuk sementara waktu ke Undang-Undang yang lama yaitu UndangUndang Nomor 25 Tahun 1992 mutatis mutandis mewajibkan Dewan Perwakilan rakyat selaku positive legislator menindak lanjuti dengan pembuatan aturan undang-

15 Mahfud MD., M., 2009, Rambu Pembatas Dan Perluasan Kewenangan Mahkamah Konstitusi. Fakultas Hukum Universitas Islam Indonesia, hlm 11 
undang koperasi yang baru.

\section{Kesimpulan}

1. Bab XIV Pasal 33 dan Pasal 34 UUD 1945 tentang Perekonomian Nasional dan Kesejahteraan Rakyat. menjadi postulat dasar konstitusi ekonomi Indonesia, yang didalamnya terdapat asas dan metode yang dikembangkan untuk menjalankan perekonomian nasional. Dalam prakteknya implementasi Pasal 33 dan Pasal 34 UUD 1945 sebagai postulat dasar konstitusi ekonomi Indonesia dapat dibangun dan dikembangkan melalui putusan Mahkamah Konstitusi terkait pegujian undang-undang terhadap Undang-undang Dasar 1945 (judicial review).

2. Koperasi merupakan salah satu role model pelaksanaan konstitusi ekonomi, yang keberadaannya dijamin dalam konstitusi. Koperasi bukan hanya sebagai prasyarat formal amanah konstitusi, namun substansi utamanya adalah memahami cara berkoperasi dalam bingkai kemandirian (ekonomi) masyarakat.

E. Saran

1. Dibutuhkan good will, keberpihakan dan politik hukum untuk menjadikan koperasi berjalan dengan baik. Koperasi masih mewarnai di Indonesia, namun hanya beberapa saja yang menjalankan prinsip-prinsip dan jati diri koperasi secara benar, hal inilah yang harus menjadi kontrol agar tidak ada pelaku sandiwara ekonomi berkedok koperasi. Fungsi fasilitator dan regulator dari negara diperlukan dengan membuat produk hukum yang sesuai dengan tujuan kesejahteraan sosial.

2. Pemerintah dan Dewan Perwakilan rakyat selaku positive legislator harus segera menindak lanjuti dengan pembuatan aturan undang-undang koperasi yang baru sehingga tidak muncul ketidak pastian hukum dan ketidakadilan.

\section{DAFTAR PUSTAKA}

Abbas Anwar, Bung Hatta dan Ekonomi Islam,2010, Jakarta, PT Kompas Media Nusantara,hlm.193

Hamid A. Attamimi, Peranan Keputusan Presiden Republik Indonesia dalam Penyelenggaraan Pemerintahan Negara; Suatu Studi Analisis Mengenai Keputusan Presiden yang Berfungsi Pengaturan dalam Kurun Waktu Pelita I-Pelita IV, Disertasi Ilmu Hukum

Fakultas Pascasarjana Universitas Indonesia, Jakarta, 1990, hal., 309

Jimly Asshiddiqie, dalam makalah Ide Konstitusi Ekonomi, 2010, hal. 3

Jurnal LPEM Pasal 33 UUD 1945 Harus Dipertahankan, Jangan Dirubah, Boleh Ditambah Ayat, Sri-Edi Swasono, Januari-Maret Vol. No.26 2002

Kamus Besar Bahasa Indonesia (2000) hal. 768

Kuntana Magnar, Inna Junaenah, dan Giri Ahmad Taufk, Tafsir MK Atas Pasal 33 UUD 1945: (Studi Atas Putusan MK Mengenai Judicial Review UU No. 7/2004, UU No. 22/2001, dan UU No. 20/2002), Jurnal Konstitusi, Volume 7, Nomor 1, Februari 2010, Hlm, 112.

Mahfud MD., M., 2009, Rambu Pembatas Dan Perluasan Kewenangan Mahkamah Konstitusi. Fakultas Hukum Universitas Islam Indonesia , hlm 11

Mubiyarto dan Boediono, 1981. Ekonomi Pancasila. Yogyakarta: BPFE UGM

Saldi Isra, 2010, Negative Legislator, http:// www.saldiisra.web.id/index.php/21- 
makalah/makalah1/302-negative$\underline{\text { legislator.html }}$

Sri-Edi Swasono dalam Seminar Implementasi Pasal 33 dan Pasal 34 UUD 1945 Gerakan Jalan Lurus, Jakarta, 6 Agustus 2008

Sri edi swasono, Ekspose Ekonomika: Mewaspadai Globalisme dan Pasar Bebas, Yogyakarta : Pusat Studi ekonomi Pancasila, 2003, hal vii

http://www.jimlyschool.com/read/ program/258/konstitusi-ekonomi

http://suroto-ideas.blogspot.com/2012/10/ meluruskan-pemikiran-hatta-tentang.html, diakses 23 Januari 2017

http://suroto-ideas.blogspot.com/2011/05/ mewujudkan-koperasi-yang-ideal-menuju. html diakses 23 Januari 2017 